\title{
Pleistocene-Holocene crustal deformation in the far-Western Himalaya
}

Saptarshi Dey, IIT Gandhinagar, Gandhinagar-382355, India. saptarshi.dey@iitgn.ac.in

Naveen Chauhan, Physical Research Laboratory, Ahmedabad- 380009, India. chauhan@prl.res.in

Debashis Nath, IIT Gandhinagar, Gandhinagar-382355, India.nath_debashis@iitgn.ac.in

Niklas W. Schaaf, Christian Albrechts University of Kiel, Germany. Niklas.schaaf@ifg.uni-kiel.de

Rasmus C. Thiede, Christian Albrechts University of Kiel, Germany. Rasmus.Thiede@ifg.uni-kiel.de Vikrant Jain, IIT Gandhinagar, Gandhinagar-382355, India. vjain@iitgn.ac.in

\section{Corresponding author email: saptarshi.dey@iitgn.ac.in}

Statement: This work has been submitted to Terra Nova in April 2021. This is a non-peer reviewed preprint submitted to EarthArXiv. If accepted, 'peer-reviewed publication DOI' link will be available on this webpage. 
4 Saptarshi Dey ${ }^{1}$, Naveen Chauhan ${ }^{2}$, Debashis Nath ${ }^{1}$, Niklas W. Schaaf ${ }^{3}$, Rasmus C. Thiede ${ }^{3}$,

5 and Vikrant Jain ${ }^{1}$

6 Corresponding author: Saptarshi Dey

\section{Significance statement}

8 Understanding the process and rates of crustal deformation on multi-millennial timescales is 9 important in seismic risk analysis. The crustal evolution of the Himalaya, imparted by the 10 ongoing intraplate convergence is highly debated and lacks data from specific areas which 11 have not witnessed high-magnitude seismicity in historical times. We present new 12 deformation rates from the western Himalaya to highlight that the intraplate convergence is partitioned among several active structures at least since Late Pleistocene. Our work underlines the existence of out-of-sequence fault activity in the western Himalaya and its' mismatch with tectonic setting of the central Nepal Himalaya.

\section{Abstract}

We present new Late Pleistocene-Holocene shortening rates across the frontal foldand-thrust belt, namely as, the Sub-Himalaya (SH) from the far-western Himalayan sector of Jammu. OSL-dated offset/ folded fluvial strath terraces suggest that the intraplate convergence is partitioned among several active structures in the SH. Estimated cumulative Late Pleistocene- Holocene shortening rate in the $\mathrm{SH}$ is $\sim 9.5 \pm 1.3 \mathrm{~mm} / \mathrm{yr}$, which is $\sim 70-75 \%$ of the measured geodetic convergence rates. Our study invokes the existence of a 350-400 km-long out-of-sequence fault-boundary within the $\mathrm{SH}$ which accommodates $\sim 5.3 \pm 2.3$ mm/yr shortening since Late Pleistocene-Holocene. Our study also highlights that ongoing crustal shortening is not accommodated only at the toe of the Himalayan wedge. 


\section{Introduction}

Quantification of ongoing crustal deformation of the Himalayan orogenic wedge is fundamental for understanding deformation processes and improving assessment of future seismic risks. Existing balanced cross-sections (e.g., Hirschmiller et al., 2014 and references therein), Late Quaternary fault-slip estimates (e.g., Lave and Avouac, 2000; Thakur et al., 2014; Vassallo et al., 2015; Dey et al., 2016b; Gavillot et al., 2016) or even geodetic shortening rate estimates (e.g., Kundu et al., 2014; Banerjee and Burgmann, 2002; Schiffmann et al., 2013) unanimously indicate that most of the crustal shortening in the western Himalaya is accommodated in the frontal fold-and-thrust belt of the Himalaya, known as the Sub-Himalaya (SH), since the Quaternary. The SH exposes an array of orogenparallel faults rooted to a low-angle basal detachment, known as the Main Himalayan Thrust (MHT) (Ni and Barazangi, 1984) (Fig. 1). Studies on late Pleistocene-Holocene activity in the western $\mathrm{SH}$ invoke the existence of multiple reactivated out-of-sequence structures in the Sub-Himalaya which portray $\sim 2-7 \mathrm{~mm} / \mathrm{yr}$ slip rates as a result of recurring high-magnitude seismic events triggered along the basal detachment (Thakur et al., 2014; Dey et al., 2016b; Gavillot et al., 2016; Cortes Aranda et al., 2018). Surprisingly, historical seismicity (Bilham, 2019) and paleo-seismic investigations (Kumar et al., 2006; Kumhara and Jayangondaperumal, 2013; Malik et al., 2015) reveal that some of these 'active' structures show no activity on shorter timescales. Therefore, these 'long-term active' but 'short-term inactive' structures pose greater seismic risks. This is one of the motivations to investigate the $\sim 200 \mathrm{~km}$-long seismic gap between the seismic zones of the 2005 Kashmir Earthquake and the 1905 Kangra Earthquake (Bilham, 2019) in the far-western Himalaya.

We used morphometric attributes, such as, longitudinal river profiles, channel width, channel steepness to identify potentially-active structures and further quantified fault displacement rates using chronologically-constrained uplifted fluvial strath surfaces. Offset/ 
51 folded fluvial straths mark differential rock uplift across potential structures (Lave and Avouac, 2000; Dey et al., 2016; Cortes Aranda et al., 2017). Our work underlines two key messages- 1 . Only $\sim 70-75 \%$ of the Himalayan shortening in the Jammu sector is accommodated within the $\mathrm{SH}$ and the remaining must be accommodated in hanging wall of the MBT and, 2. There exists a $~ 350-400 \mathrm{~km}$ long out-of-sequence fault boundary in the western SH that accommodates $\sim 30-50 \%$ of the total Himalayan shortening.

\section{Geological background}

The $\mathrm{SH}$ in Jammu Himalaya is $~ 70-80 \mathrm{~km}$ wide and exposes rocks of Murree Formation and the Siwaliks (Fig. 1b). The SH units are folded and thrusted by multiple fault systems (Fig. 1c) - the Murree Thrust (MT), the Tanhal Thrust (TT) (known as the Main Riasi Thrust (MRT) in the Kashmir Himalaya) and the Mandili-Kishanpur Thrust (MKT) (known as the Frontal Riasi Thrust (FRT) in the Kashmir Himalaya). The wedge margin fault (Himalayan Frontal Fault, HFT) in this sector is blind and expressed by a growing anticline, the Surain Mastgarh Anticline (SMA) (Fuchs, 1975; Raivermann et al., 1994; Gavillot et al., 2018). The uplift of the MKT causes the tectonic damming, which forms the Udhampur piggyback basin on its hanging wall (Gavillot et al., 2016; Malik and Mohanty, 2017). In Table 1, we compiled the previously-published deformation rates from the Kashmir Himalaya, Jammu Himalaya and the Kangra Recess. The FRT and JMT are the contemporary structures of MKT in the neighboring fault segments (Table 1). The GPS-derived convergence rate in Jammu sector is $13 \pm 1 \mathrm{~mm} / \mathrm{yr}$ (Schiffman et al., 2013).

\section{Methods and results}

\subsection{Field observation}


levels of terraces. We mapped the fluvial terraces and measured their average height with respect to the present base level using multi-point averaged hand-held GPS measurements and high resolution DEM dataset. In the northern part of the UB, we found $\sim 100 \mathrm{~m}$ thick sequence of fluvial boulders intercalated with discontinuous meter-thick sand-silt layers. The southern part of the basin, however, is devoid of large-scale Late Pleistocene- Holocene alluvium and the fluvial terraces are only capped by 1-3 m-thick veneer of alluvium. In the hanging wall of the MKT, we recognize six different fluvial terrace levels (Fig.2a, 5a). We named them T1-T6, according to the decreasing heights from the Tawi River (Fig. 4a). Terrace levels T3-T6 are identified as straths as they only have 1-3 m thick alluvium atop the tilted SH bedrock units.

Along the Ujh R. section (cf. Fig. 1c), we identified 3 levels of fluvial straths (U1, U2 and U3) (Fig. 4a). The U3 strath level is the most ubiquitous and is identified by a continuous 1-1.5 m-thick layer of light brown silt sitting atop the tilted bedrock strath (Fig. $2 \mathrm{~g}, 6 \mathrm{a})$. In the field we measured a change in height of the U3 strath with respect to the fluvial base level between $\sim 8$ and $28 \mathrm{~m}$ over a distance of $20 \mathrm{~km}$ (Fig. 4b).

\subsection{Morphometry}

Longitudinal river profiles, steepness indices and channel width measurement are often used as indicators of active tectonics (Seeber and Gornitz, 1983; Kirby and Whipple, 2012; Allen et al., 2013). We used 12.5m ALOS PALSAR terrain-corrected DEM for our morphometric analysis. Details about morphometric indices and conditions applied are listed in Appendix 1. Changes of morphometric indices across the MKT and other faults are shown in Fig. 3 and 5. 

representing the upstream-head of steep river segments, $\sim 4 \mathrm{~km}$ and $\sim 5 \mathrm{~km}$ upstream from the MKT and MT, respectively (Fig. 5a). Channel width in the steep sections are lower ( 40 m) compared to the low-slope segments (> $80 \mathrm{~m}$ ) or even in the UB (60-80 m) (Fig. 3b). The steep segments are characterized by transient increase in normalized steepness indices $\left(\mathrm{k}_{\mathrm{sn}}\right)$ values from $<200$ to $\geq 400$ (Fig. 5c). Longitudinal profile of the Ujh R. doesn't show any knickpoints on the profile (Supplementary Fig. S2), but the channel width is systematically low at the hinge-zone of the anticline (Supplementary Fig. S3).

\subsection{Luminescence dating for estimation of terrace abandonment age}

We applied optically-stimulated luminescence (OSL) dating technique to obtain the timing of sedimentation above fluvial strath surfaces and interpret those as the maximum abandonment ages of the fluvial strath levels exposed across the MKT. For that we sampled a total of 9 samples from fine sand and silt layers in the thin veneer of alluvium exposed above the bedrock straths along the Tawi and Ujh River. Information about OSL samples and their stratigraphic significance are listed in Table 1. We opted for OSL double-SAR protocol for equivalent dose (De) estimation (Thomsen et al., 2008) using 24 aliquots of each sample (Supplementary Fig. S5). The dose rate was estimated using the online software DRAC (Durcan et al., 2015) from the data of Uranium (U), Thorium (Th), and Potassium (K) measured using $\alpha, \beta$ and $\gamma$ counters. We opted for Central Age Model for estimation of mean De (Bailey and Arnold, 2006).

In the hanging wall of MKT, samples TW-01 and TW-02 above the T3 strath surface yield ages of $\sim 24.1 \pm 1.5 \mathrm{kyr}$ and $22.3 \pm 1.3 \mathrm{kyr}$, respectively, and match stratigraphic order (Fig. 6a). Samples TW-03 (8.6 $\pm 1.0 \mathrm{kyr})$ and TW-04 (9.6 $\pm 0.7 \mathrm{kyr})$ were taken above the T5 and T4 terrace levels, respectively - even if the errors overlap and they yield the same age 
and the ages match with stratigraphic order. On the footwall of the MKT, we have only one OSL age from above the 55m-high-strath level, which yields a depositional age of $20.3 \pm 0.8$ kyr (sample TW-05), therefore this represents T3 in the hanging wall. Sample TW-06, taken $\sim 27 \mathrm{~m}$ above the regional base-level yield a depositional age of $9.7 \pm 0.3 \mathrm{kyr}$, and we correlate this with terrace T4, the most well-preserved and regionally-extensive terrace level. Along the Ujh River section, we have three OSL ages- two ages from the regionally most prominent and best-preserved terrace level (U3), which we relate to T4 terraces along the Tawi river (sample UJ-01: 10.2 $\pm 0.7 \mathrm{kyr}$ and UJ-02: $9.8 \pm 0.8 \mathrm{kyr}$ ) and one age from the top of U1 terrace

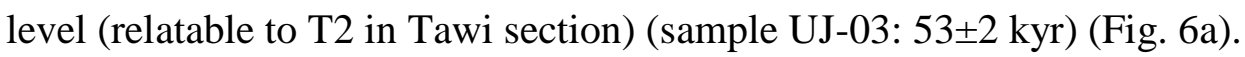

\section{Discussion}

In this section, we discuss the variability in bedrock incision rates and their implications in crustal deformation and compare our results with previously-published deformation rates for a regional overview of ongoing crustal deformation in the Western Himalaya. But, first we discuss how variations in morphometric indices were used to identify active structures.

\subsection{Identification of active tectonics using morphometry}

Knickpoint K1 (Fig.3a) is not lithologically-controlled. On the contrary, the dip of bedrock units increases downstream from $30-35^{\circ}$ to $45-50^{\circ}$. The channel width decreases (Fig. 3b) and the ksn value increases (Fig. 3c). Combining these observations, we propose that the upstream and downstream part of the K1 may actually represent two ramp segments, i.e., ramp 1 and ramp 2 and $\mathrm{K} 1$ represents the bend of two ramp segments at the surface. The steeper ramp (ramp 2) has higher bedrock incision (at C2) than ramp 1 (at C1) (Fig. 3d). In 
the MKT footwall, the bedrock incision is less than in the hanging wall (at C3, the height of T4 strath is $31 \mathrm{~m})$.

\subsection{Variability in bedrock incision implies tectonic uplift}

Fluvial strath terrace heights and their corresponding abandonment ages are used to calculate fluvial incision rate across the MKT, TT and SMA (Table 3). We observe higher incision rates in the hanging wall of the MKT $(5.2 \pm 0.2 \mathrm{~mm} / \mathrm{yr})$ compared to the footwall ( $2.5 \pm 0.2 \mathrm{~mm} / \mathrm{yr})$. Note that, the bedrock incision in the footwall of the MKT is driven by the growth of the SMA. Similar higher incision rates are obtained on the hanging wall of the TT ( $7 \mathrm{~mm} / \mathrm{yr}$ ). Incision rates vary between $1-2.7 \mathrm{~mm} / \mathrm{yr}$ across the SMA. In our previous study in the Kangra Basin, we showed that terrace abandonment and fluvial incision in intermontane piggyback basins can be triggered by a combination of tectonic and climatic forcing (Dey et al., 2016a and 2016b). However, climatically-enforced fluvial incision would warrant a uniform incision. Therefore, we infer the differential incision on hanging wall and footwall side of the fault to be tectonically-driven.

\subsection{Crustal shortening estimates across SH structures}

Offset fluvial straths have been used to quantify rock uplift rates across active structures. In Fig. 5a, we illustrate how terraces surface of T3-T5 are regionally distributed across the MKT. Applying orthogonal profile projection method and considering height uncertainty, we deduce $58 \pm 3 \mathrm{~m}$ and $30 \pm 2 \mathrm{~m}$ offset across the $\sim 21$ kyr-old T3 terrace and $\sim 10$ kyr-old T4 terrace, respectively (Tawi River section). We interpret this offset as differential uplift across the active fault and it can be equated to rock uplift on the fault-ramp (Dey et al., 2016; Lave and Avouac, 2000). Using the mean terrace abandonment ages we further calculated the differential uplift rate ranging $3.0 \pm 0.5 \mathrm{~mm} / \mathrm{yr}$ (Fig. 5a). Similar profile projection method was used in our previous study on the JMT (cf Fig. 7 in Dey et al., 2016b). 
Assuming the dip of MKT-fault ramp to be $30-35^{\circ}$, (using field data on structural orientation of the ramp of the MKT and balanced cross-section (Gavillot et al., 2018)), this translates into a shortening rate of $4.5 \pm 1.0-5.1 \pm 0.9 \mathrm{~mm} / \mathrm{yr}$. Similar pattern of offset of the $10 \mathrm{kyr}-\mathrm{old} \mathrm{T} 4$ surface is seen across the MT (Fig. 5b). The deduced shortening rate (using fault-ramp angle of $60^{\circ}$ ) is $1.6 \pm 0.2 \mathrm{~mm} / \mathrm{yr}$. In case of the SMA, the U3 terrace shows variation in bedrock incision up to 8-28 $\mathrm{m}$ while, the same U3 level has a height of 4-5 m, away from the fold. We calculated the uplift due to folding by taking the 'undisturbed' U3 height as baseline. Horizontal component of shortening (Fig. 6b) due to active folding was calculated using the fold geometry (Fig. 6c). Component of shortening on the southern and northern limb of SMA are $1.8 \pm 0.1 \mathrm{~mm} / \mathrm{yr}$ and $1.3 \mathrm{~mm} / \mathrm{yr}$, respectively. So, the tentative shortening rate across the SMA is $3.1 \pm 0.1 \mathrm{~mm} / \mathrm{yr}$.

\subsection{Regional significance of our study}

The cumulative crustal shortening rate accommodated within the $\mathrm{SH}$ is $9.5 \pm 1.3$ $\mathrm{mm} / \mathrm{yr}$. Assuming the geodetic convergence rates to be consistent over geologic timescales, our results indicate that $\sim 70-75 \%$ of the total Himalayan shortening is accommodated in the SH since at least Late Pleistocene-Holocene. Published shortening rates on the FRT in the Kashmir Himalaya is $4.5 \pm 1.5 \mathrm{~mm} / \mathrm{yr}$ since $39 \mathrm{ka}$ (Gavillot et al., 2016), while shortening on the JMT in the Kangra Recess is 3.5-4.2 mm/yr since 32 ka (Thakur et al., 2014) or, 5.6 $\pm 0.8-$ 7.5 $\pm 1.1 \mathrm{~mm} / \mathrm{yr}$ since $10 \mathrm{ka}$ (Dey et al., 2016b). Their contemporary in the Jammu SH, the MKT shortens at a rate of $4.5 \pm 1.0-5.1 \pm 0.9 \mathrm{~mm} / \mathrm{yr}$ which is within the range proposed by aforementioned studies. Therefore, we propose that the FRT-MKT-JMT represent segments of a single surface-rupture fault that runs orogen parallel for $\sim 350-400 \mathrm{~km}$ and accommodates $\sim 30-50 \%$ of the total Himalayan shortening $(5.3 \pm 2.3 \mathrm{~mm} / \mathrm{yr})$. This implies that it is one of most active out-of-sequence fault since Late Pleistocene-Holocene in the entire Himalaya. Nevertheless, our cumulative shortening rate estimate also hint that another 
3-4 mm/yr shortening has to be accommodated to compensate geodetically-obtained convergence rate. Till date we have not recognized more active faulting within the SH or the MBT. But, fluvial incision at rates at $\geq 3 \mathrm{~mm} / \mathrm{yr}$ within the Kishtwar Window (KW) over similar timescales indicated that the shortening deficit is likely accommodated within the KW (Dey et al., 2021, accepted).

\section{Conclusions}

Unpaired bedrock strath surfaces preserved along the Tawi and Ujh River document differential uplift of the SH strata and most likely triggered by ongoing crustal shortening across major fault systems. We conclude-

a. Shortening rate across the MKT and TT in the range of $4.7 \pm 1.2 \mathrm{~mm} / \mathrm{yr}$ since $20 \mathrm{ka}$ and $1.6 \pm 0.2 \mathrm{~mm} / \mathrm{yr}$ since $10 \mathrm{ka}$, respectively.

b. Tentative Holocene shortening rate across the SMA is $3.1 \pm 0.1 \mathrm{~mm} / \mathrm{yr}$.

c. Cumulative shortening rate across the $\mathrm{SH}$ is $9.5 \pm 1.3 \mathrm{~mm} / \mathrm{yr}$ which relates to $\sim 70-75 \%$ of the geodetic convergence rates estimated for the entire western Himalaya.

d. FRT-MKT-JMT is a 350-400 km-long single out-of-sequence fault-boundary accommodating $30-50 \%$ of the total Himalayan shortening. It is regionally the mostactive structure at least since late Pleistocene if not longer.

e. Up to 3-4 mm/yr crustal shortening may still be accommodated in the hanging wall the MBT, most likely within the KW.

\section{Acknowledgements}

S. Dey is supported by DST-INSPIRE faculty research grant (grant \#DST/INSPIRE/04/2017/003278) from Department of Science and Technology, Govt. of 
India at IIT Gandhinagar. N. Schaaf and R. Thiede acknowledge support by Deutsche

217 Forschungsgemeinschaft (DFG - TH 1317/9-1). We thank S. Das and C. Singh for logistic

218

219

220

221

222

223

224

225

226

227

228

229

230 support in the fieldwork. We also thank M. Biswas for helping in statistical error propagation used in this study.

\section{References}

Ader, T., Avouac, J. P., Liu-Zeng, J., Lyon-Caen, H., Bollinger, L., Galetzka, J., Genrich, J., Thomas, M., Chanard, K., Sapkota, S.N., Rajaure, S.,\& Flouzat, M. (2012). Convergence rate across the Nepal Himalaya and interseismic coupling on the Main Himalayan Thrust: Implications for seismic hazard. Journal of Geophysical Research: Solid Earth, 117(B4).

Aitken, M. J. (1998). Introduction to optical dating: the dating of Quaternary sediments by the use of photon-stimulated luminescence. Clarendon Press.

Allen, G. H., Barnes, J. B., Pavelsky, T. M., \& Kirby, E. (2013). Lithologic and tectonic controls on bedrock channel form at the northwest Himalayan front. Journal of Geophysical Research: Earth Surface, 118(3), 1806-1825.

Anilkumar, A. (2016, December). Shortening rate of the NW-Himalaya, across the Surin Mastgarh Anticline, Chenab Re-entrant, Jammu. In AGU Fall Meeting Abstracts (Vol. 2016, pp. T23B-2915).

Bailey, R. M., \& Arnold, L. J. (2006). Statistical modelling of single grain quartz De distributions and an assessment of procedures for estimating burial dose. Quaternary Science Reviews, 25(19-20), 2475-2502. 
Banerjee, P., \& Bürgmann, R. (2002). Convergence across the northwest Himalaya from GPS measurements. Geophysical Research Letters, 29(13), 30-1.

Bilham, R. (2019). Himalayan earthquakes: a review of historical seismicity and early 21st century slip potential. Geological Society, London, Special Publications, 483(1), 423-482.

Bilham, R., Larson, K., \& Freymueller, J. (1997). GPS measurements of present-day convergence across the Nepal Himalaya. Nature, 386(6620), 61-64.

Burbank, D. W., Leland, J., Fielding, E., Anderson, R. S., Brozovic, N., Reid, M. R., \& Duncan, C. (1996). Bedrock incision, rock uplift and threshold hillslopes in the northwestern Himalayas. Nature, 379(6565), 505-510.

Burgess, W. P., Yin, A., Dubey, C. S., Shen, Z. K., \& Kelty, T. K. (2012). Holocene shortening across the Main Frontal Thrust zone in the eastern Himalaya. Earth and Planetary Science Letters, 357, 152-167.

Cortés-Aranda, J., Mugnier, J. L., Jouanne, F., Vassallo, R., Carcaillet, J., \& Awan, A. A. (2017). Holocene shortening rates and seismic hazard assessment for the frontal Potwar Plateau, NW Himalaya of Pakistan: Insights from 10Be concentrations on fluvial terraces

Cortes-Aranda, J., Vassallo, R., Jomard, H., Pousse-Beltrán, L., Astudillo, L., Mugnier, J.L., Jouanne, F., Malik, M. and Carcaillet, J. (2018). Late quaternary out-of-sequence deformation in the innermost Kangra Reentrant, NW Himalaya of India: seismic potential appraisal from 10Be dated fluvial terraces. Journal of Asian Earth Sciences, 158, 140152. 
Dey, S., Kaushal, R. K., Sonam, \& Jain, V. (2019). Spatiotemporal variability of neotectonic activity along the Southern Himalayan front: A geomorphic perspective. Journal of Geodynamics, 129, 237-246.

Dey, S., Thiede, R. C., Schildgen, T. F., Wittmann, H., Bookhagen, B., Scherler, D., Jain, V., \& Strecker, M. R. (2016a). Climate-driven sediment aggradation and incision since the late Pleistocene in the NW Himalaya, India. Earth and Planetary Science Letters, 449, 321-331.

Dey, S., Thiede, R. C., Schildgen, T. F., Wittmann, H., Bookhagen, B., Scherler, D., \&

Strecker, M. R. (2016b). Holocene internal shortening within the northwest SubHimalaya: Out-of-sequence faulting of the Jwalamukhi Thrust, India. Tectonics, 35(11), 2677-2697.

Durcan, J. A., King, G. E., \& Duller, G. A. (2015). DRAC: Dose Rate and Age Calculator for trapped charge dating. Quaternary Geochronology, 28, 54-61.

Elliott, J. R., Jolivet, R., González, P. J., Avouac, J. P., Hollingsworth, J., Searle, M. P., \& Stevens, V. L. (2016). Himalayan megathrust geometry and relation to topography revealed by the Gorkha earthquake. Nature Geoscience, 9(2), 174-180.

Flint, J. J. (1974). Stream gradient as a function of order, magnitude, and discharge. Water Resources Research, 10(5), 969-973.

Gavillot, Y., Meigs, A. J., Sousa, F. J., Stockli, D., Yule, D., \& Malik, M. (2018). Late Cenozoic foreland-to-hinterland low-temperature exhumation history of the Kashmir Himalaya. Tectonics, 37(9), 3041-3068.

Gavillot, Y., Meigs, A., Yule, D., Heermance, R., Rittenour, T., Madugo, C., \& Malik, M. (2016). Shortening rate and Holocene surface rupture on the Riasi fault system in the 
Kashmir Himalaya: active thrusting within the Northwest Himalayan orogenic wedge. Bulletin, 128(7-8), 1070-1094.

Hirschmiller, J., Grujic, D., Bookhagen, B., Coutand, I., Huyghe, P., Mugnier, J. L., \& Ojha, T. (2014). What controls the growth of the Himalayan foreland fold-and-thrust belt?. Geology, 42(3), 247-250.

Huntley, D. J., Godfrey-Smith, D. I., \& Thewalt, M. L. (1985). Optical dating of sediments. Nature, 313(5998), 105-107.

Jagtap, S., Jayangondaperumal, R., Singh, I., \& Singh Negi, S. (2018, April). Active deformation within the blind thrust front of Jammu Kashmir Himalaya: A fluvial record 
Kumar, S., Wesnousky, S. G., Rockwell, T. K., Briggs, R. W., Thakur, V. C., \& Jayangondaperumal, R. (2006). Paleoseismic evidence of great surface rupture earthquakes along the Indian Himalaya. Journal of Geophysical Research: Solid Earth, 111(B3).

Kundu, B., Yadav, R. K., Bali, B. S., Chowdhury, S., \& Gahalaut, V. K. (2014). Oblique convergence and slip partitioning in the NW Himalaya: Implications from GPS measurements. Tectonics, 33(10), 2013-2024.

Lavé, J., \& Avouac, J. P. (2000). Active folding of fluvial terraces across the Siwaliks Hills, Himalayas of central Nepal. Journal of Geophysical Research: Solid Earth, 105(B3), 5735-5770.

Lavé, J., \& Avouac, J. P. (2001). Fluvial incision and tectonic uplift across the Himalayas of central Nepal. Journal of Geophysical Research: Solid Earth, 106(B11), 26561-26591. Malik, J. N., Naik, S. P., Sahoo, S., Okumura, K., \& Mohanty, A. (2017). Paleoseismic evidence of the CE 1505 (?) and CE 1803 earthquakes from the foothill zone of the Kumaon Himalaya along the Himalayan Frontal Thrust (HFT), India. Tectonophysics, 714, 133-145.

Malik, J. N., Sahoo, S., Satuluri, S., \& Okumura, K. (2015). Active fault and paleoseismic studies in Kangra valley: Evidence of surface rupture of a great Himalayan 1905 Kangra earthquake (M w 7.8), Northwest Himalaya, India. Bulletin of the Seismological Society of America, 105(5), 2325-2342.

Mugnier, J. L., Gajurel, A., Huyghe, P., Jayangondaperumal, R., Jouanne, F., \& Upreti, B. (2013). Structural interpretation of the great earthquakes of the last millennium in the central Himalaya. Earth-Science Reviews, 127, 30-47. 
Mukul, M., Jaiswal, M., \& Singhvi, A. K. (2007). Timing of recent out-of-sequence active deformation in the frontal Himalayan wedge: Insights from the Darjiling subHimalaya, India. Geology, 35(11), 999-1002.

Nábělek, J., Hetényi, G., Vergne, J., Sapkota, S., Kafle, B., Jiang, M., ... \& Huang, B. S. (2009). Underplating in the Himalaya-Tibet collision zone revealed by the Hi-CLIMB experiment. Science, 325(5946), 1371-1374.

Ni, J., and Barazangi, M. (1984). Seismotectonics of the Himalayan collision zone: Geometry of the underthrusting Indian plate beneath the Himalaya. Journal of Geophysical Research: Solid Earth, 89(B2), 1147-1163.

Olley, J., Caitcheon, G., \& Murray, A. (1998). The distribution of apparent dose as implications for dating young sediments. Quaternary Science Reviews, 17(11), 10331040.

Owen, L. A., Finkel, R. C., \& Caffee, M. W. (2002). A note on the extent of glaciation throughout the Himalaya during the global Last Glacial Maximum. Quaternary Science Reviews, 21(1-3), 147-157.

Pant, R. K., Juyal, N., Basavaiah, N., \& Singhvi, A. K. (2006). Late Quaternary glaciation and seismicity in the Higher Central Himalaya: evidence from Shalang basin (Goriganga), Uttaranchal. Current Science, 1500-1505.

Pazzaglia, F. J., \& Brandon, M. T. (2001). A fluvial record of long-term steady-state uplift and erosion across the Cascadia forearc high, western Washington State. American Journal of Science, 301(4-5), 385-431. 
Perron, J. T., \& Royden, L. (2013). An integral approach to bedrock river profile analysis. Earth Surface Processes and Landforms, 38(6), 570-576.

Powers, P. M., Lillie, R. J., \& Yeats, R. S. (1998). Structure and shortening of the Kangra and Dehra Dun reentrants, sub-Himalaya, India. Geological Society of America Bulletin, 110(8), 1010-1027.

Raiverman, V., Srivastava, A. K., \& Prasad, D. N. (1994). Structural style in northwestern Himalayan foothills.

Rendell, H. M., Webster, S. E., \& Sheffer, N. L. (1994). Underwater bleaching of signals from sediment grains: new experimental data. Quaternary Science Reviews, 13(5-7), 433435.

Schiffman, C., Bali, B. S., Szeliga, W., \& Bilham, R. (2013). Seismic slip deficit in the Kashmir Himalaya from GPS observations. Geophysical Research Letters, 40(21), 56425645.

Schwanghart, W., \& Scherler, D. (2014). TopoToolbox 2-MATLAB-based software for topographic analysis and modeling in Earth surface sciences. Earth Surface Dynamics, 2(1), 1-7.

Shah, A. A., \& Malik, J. N. (2017). Four major unknown active faults identified, using satellite data, in India and Pakistan portions of NW Himalaya. Natural Hazards, 88(3), Shukla, T., Mehta, M., Dobhal, D. P., Bohra, A., Pratap, B., \& Kumar, A. (2020). LateHolocene climate response and glacial fluctuations revealed by the sediment record of the monsoon-dominated Chorabari Lake, Central Himalaya. The Holocene, 30(7), 953-965. 
Singh, A., Thomsen, K. J., Sinha, R., Buylaert, J. P., Carter, A., Mark, D. F., ... \& Gupta,

S. (2017). Counter-intuitive influence of Himalayan river morphodynamics on Indus

Singhvi, A. K., \& Kar, A. (2004). The aeolian sedimentation record of the Thar

Srivastava, P., \& Misra, D. K. (2008). Morpho-sedimentary records of active tectonics at the Kameng river exit, NE Himalaya. Geomorphology, 96(1-2), 187-198.

Srivastava, P., \& Misra, D. K. (2012). Optically stimulated luminescence chronology of terrace sediments of Siang River, Higher NE Himalaya: Comparison of Quartz and Feldspar chronometers. Journal of the Geological Society of India, 79(3), 252-258.

Srivastava, P., Rajak, M. K., \& Singh, L. P. (2009). Late Quaternary alluvial fans and paleosols of the Kangra basin, NW Himalaya: Tectonic and paleoclimatic implications. Catena, 76(2), 135-154.

Stevens, V. L., \& Avouac, J. P. (2015). Interseismic coupling on the main Himalayan thrust. Geophysical Research Letters, 42(14), 5828-5837.

Thakur, V. C., Joshi, M., Sahoo, D., Suresh, N., Jayangondapermal, R., \& Singh, A. (2014). Partitioning of convergence in Northwest Sub-Himalaya: estimation of late Quaternary uplift and convergence rates across the Kangra reentrant, North India. International Journal of Earth Sciences, 103(4), 1037-1056.

Thiede, R., Robert, X., Stübner, K., Dey, S., \& Faruhn, J. (2017). Sustained out-ofsequence shortening along a tectonically active segment of the Main Boundary thrust: The Dhauladhar Range in the northwestern Himalaya. Lithosphere, 9(5), 715-725. 

rates of various luminescence signals from feldspar-rich sediment extracts. Radiation measurements, 43(9-10), 1474-1486.

Vassallo, R., Mugnier, J. L., Vignon, V., Malik, M. A., Jayangondaperumal, R., deformation in northwestern Himalaya. Earth and Planetary Science Letters, 411, 241252. (2015 or 2016, I could not find it for 2016). convergence along the Himalayan Frontal Thrust of India. Tectonics, 18(6), 967-976. patterns, and erosion during rapid post-12 Ma uplift of the Bolivian Andes." Lithosphere 6(4): 251-268.

407 Yin, A., \& Harrison, T. M. (2000). Geologic evolution of the Himalayan-Tibetan orogen. Annual review of earth and planetary sciences, 28(1), 211-280. 


\section{Figures}
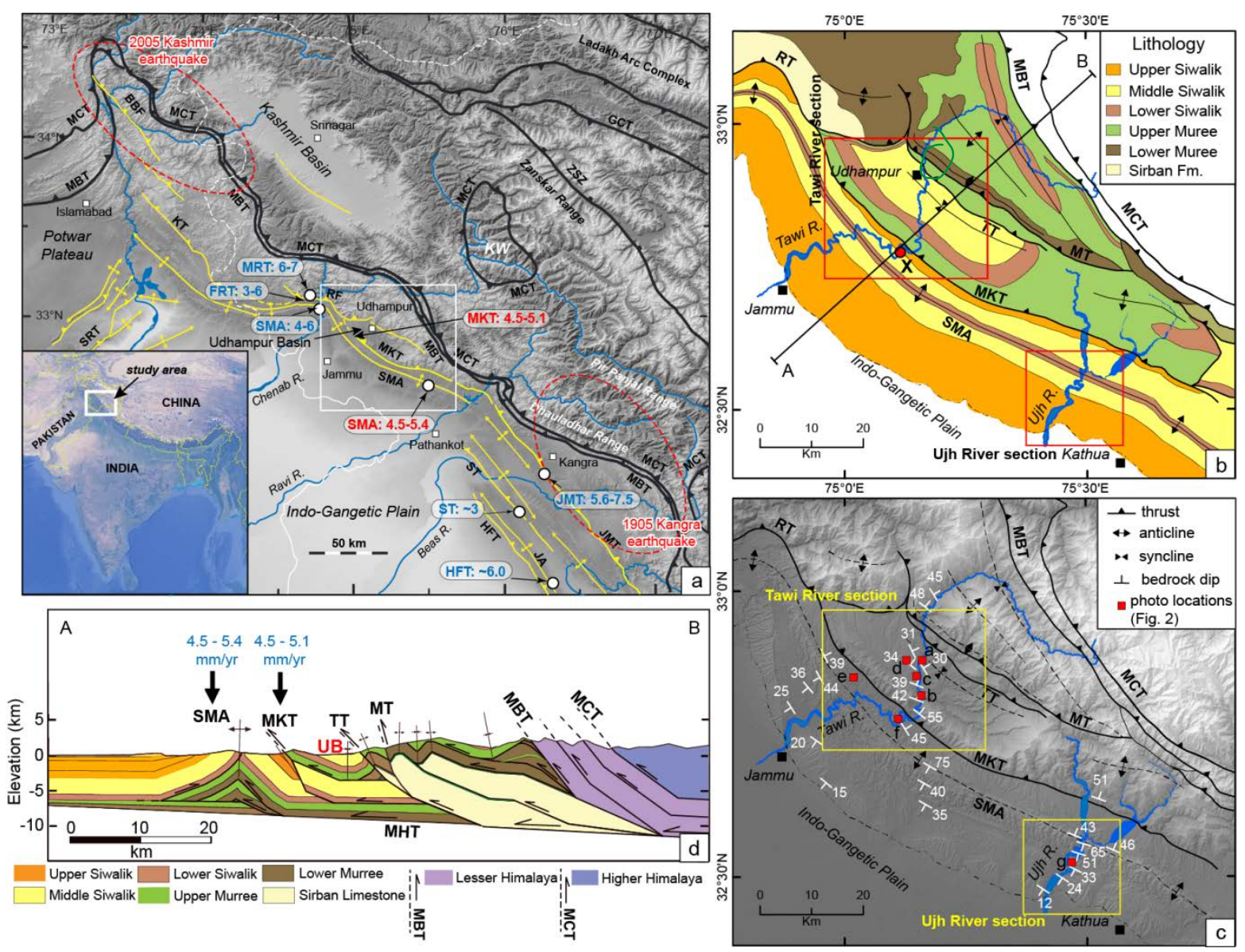

Figure 1: (a) A general overview map of the far-western Himalaya showing major tectonic

line) along with Published Holocene shortening rates from nearby active structures (Vassallo et al.,

2015; Gavillot et al., 2016; Thakur et al., 2014; Dey et al., 2016). (b) Lithological map of the Jammu

419 Himalaya (modified after Steck, 2003 and Gavillot et al. 2018). The studied river sections of the Tawi

and the Ujh are marked with red boxes. The point $\mathrm{X}$ (marked by red circle) is the pour-point used for

421 longitudinal profile analysis shown in Fig. 3a. (c) Bedrock structural orientations along with field-

422 documented tectonic boundaries in the Jammu Himalaya. Letters refer to the locations of the field photographs in Fig. 2. (d) Partially-balanced cross-section across the Jammu Himalaya along line AB 

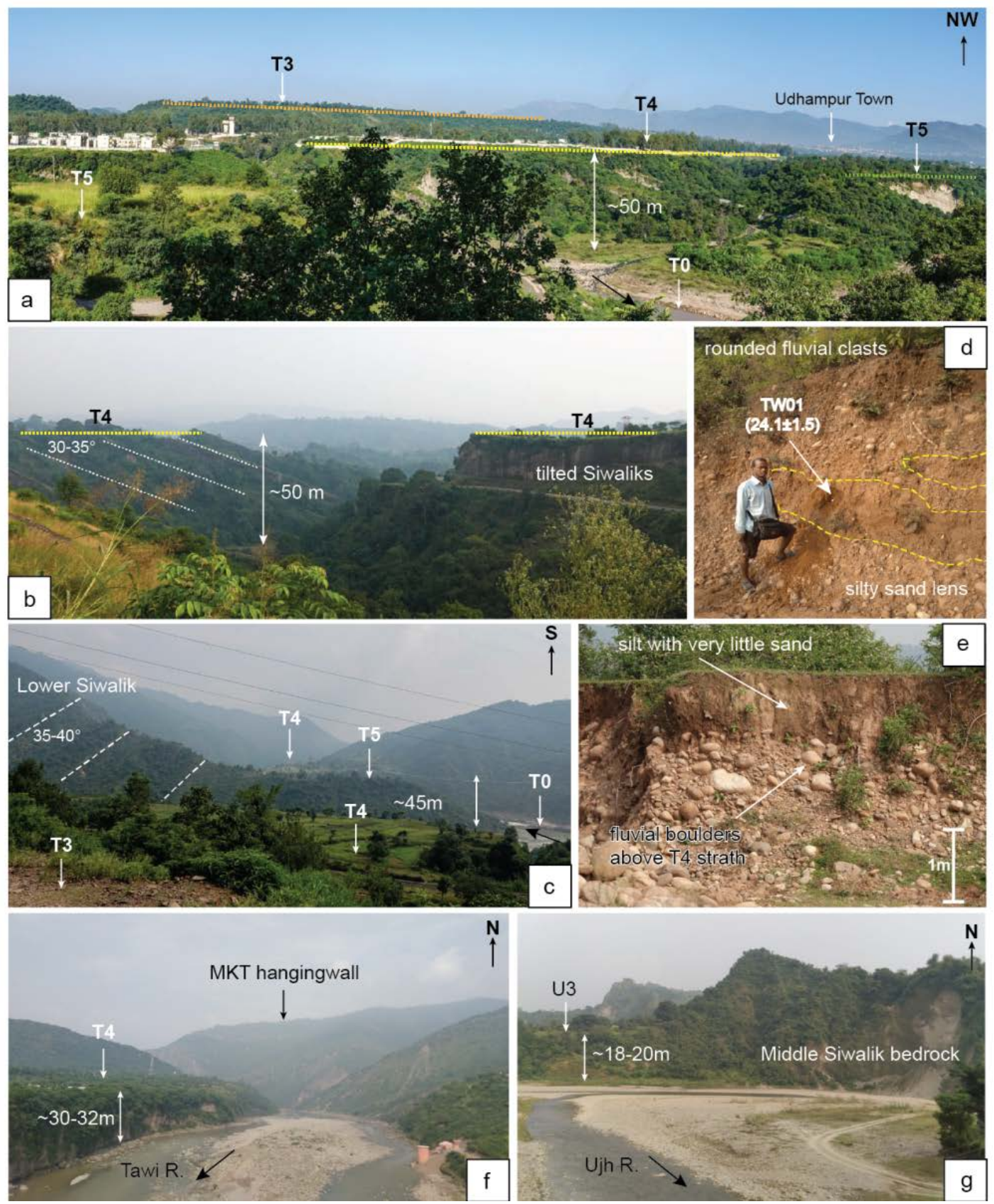

430 Figure 2: Field photographs, see Fig. 1c for locations. (a) Fluvial strath terraces preserved in

431 Udhampur Basin (UB) in the hanging wall of the MKT. (b) T4 strath above the ramp of the MKT 
showing strong incision into Siwalik 'bedrock'. (c) Fluvial strath levels exposed along the Tawi R. at

433 the southern margin of the UB (d) OSL-dated silty sand layer in the alluvium covering the Siwalik

434 'bedrock' units - interpreted as being deposited shortly before fluvial bedrock incision initiated resulting surface abandonment and terrace formation. (e) Fluvial sediment cover above the T4 strath. the fluvial channel of the Ujh River - see Fig. 6.

439
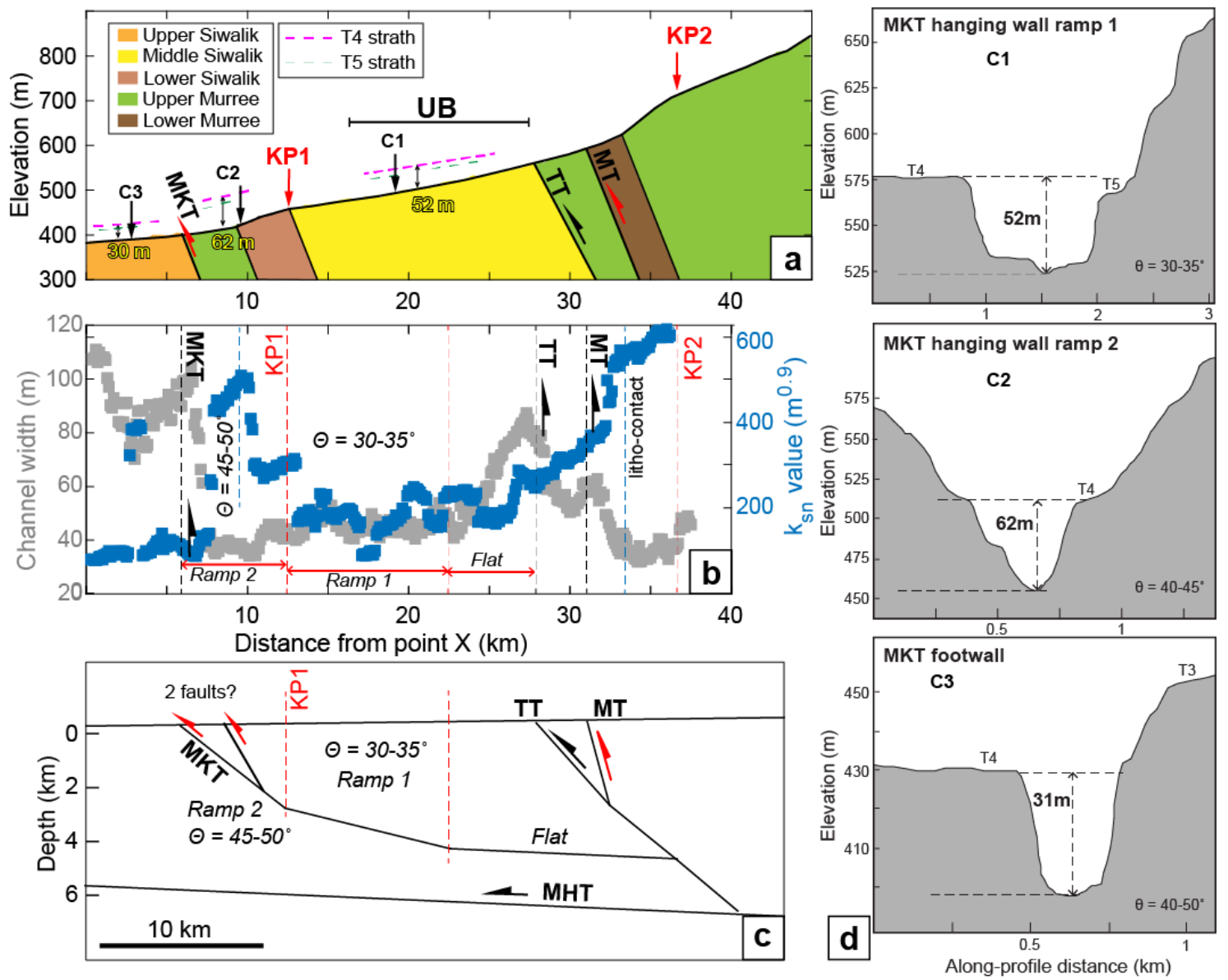

Figure 3: (a) Longitudinal profile of the Tawi River across the MKT, upstream from point X (cf. Fig.

1b) showing two major knickpoints, $\mathrm{K} 1$ and $\mathrm{K} 2 . \mathrm{C} 1, \mathrm{C} 2$ and $\mathrm{C} 3$ are river-flow perpendicular

topographic cross-sections indicated in a. (b) Bedrock channel width measurements along the profile show a lowering of the channel width across the ramp segments (ramp 1 and ramp 2) of the MKT. $\mathrm{k}_{\mathrm{sn}}$ values plotted against the longitudinal profile length show an increase across the ramp segments corroborating with our field finding of stronger incision potential (steeper river gradient) in the 
hanging wall of the MKT. (c) Schematic illustration of sub-surface structural orientations beneath the

447 UB, deduced from a previously-published balanced cross-section (Gavillot et al., 2018) and verified

with our own field measurements. We propose two ramp segments, Ramp 1 and Ramp 2 on the MKT,

which have higher dip angle than the flat fault segment located to the north. (d) Terrace and valley

length perpendicular profiles across the Tawi River at locations C1, C2 and C3 show differential incision depth of T4. We relate the observed difference in terrace-heights to active faulting and uplift of the MKT hanging wall, fostering fluvial incision in the hanging wall, as the river tends to equilibrate its longitudinal river-profile. Therefore, we assume that the variation in terrace heights documented in field can be used as a marker horizon to measure differential uplift across the major fault system and subsequent re-adjustment of the fluvial network.
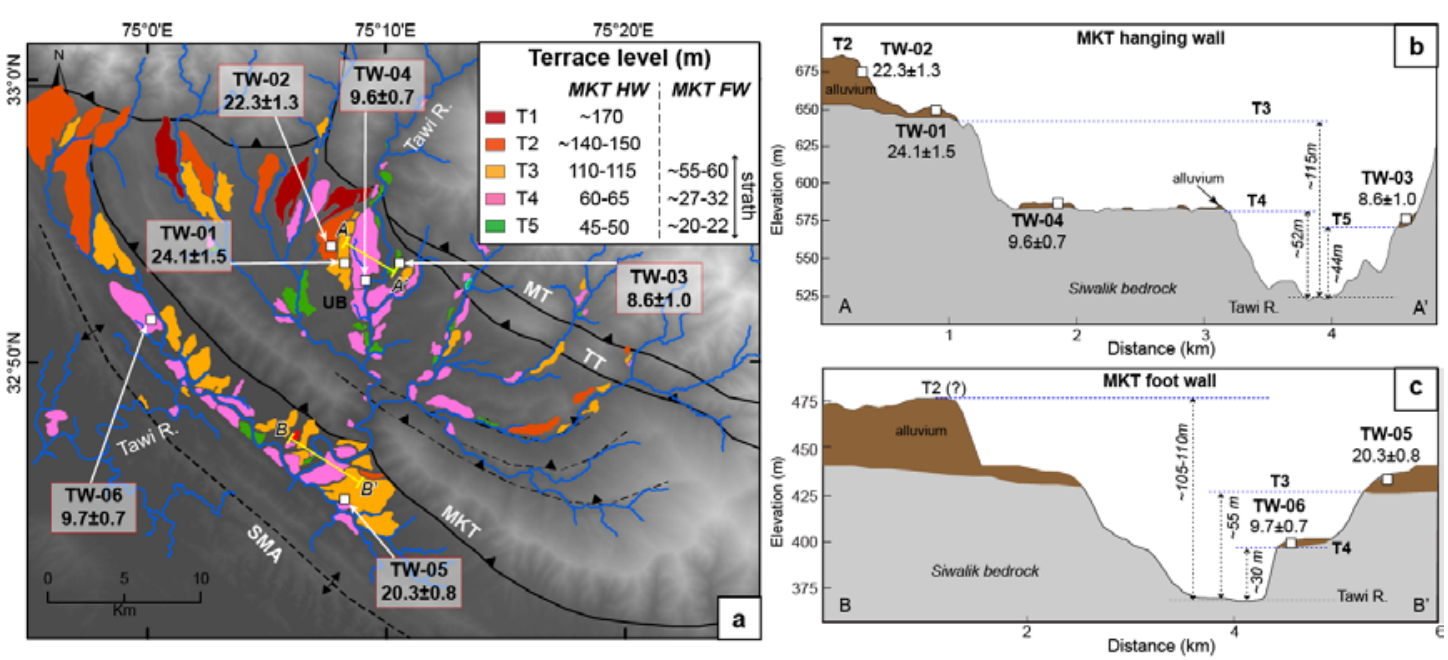

Figure 4: (a) Fluvial terrace map and its relative heights to present stem river of fluvial network of the intramontane Udhampur Basin and surroundings. (b) River perpendicular topographic profile along AA' shows the mean terrace heights with respect to the present-day stem river in the hanging wall of the MKT. (c) Across-river topographic profile along BB' in the footwall of the MKT. Please note the relative height difference of the same strath surfaces across the MKT. Dated straths and relative heights are used for calculation of fault displacement rates - see Fig. 5. 


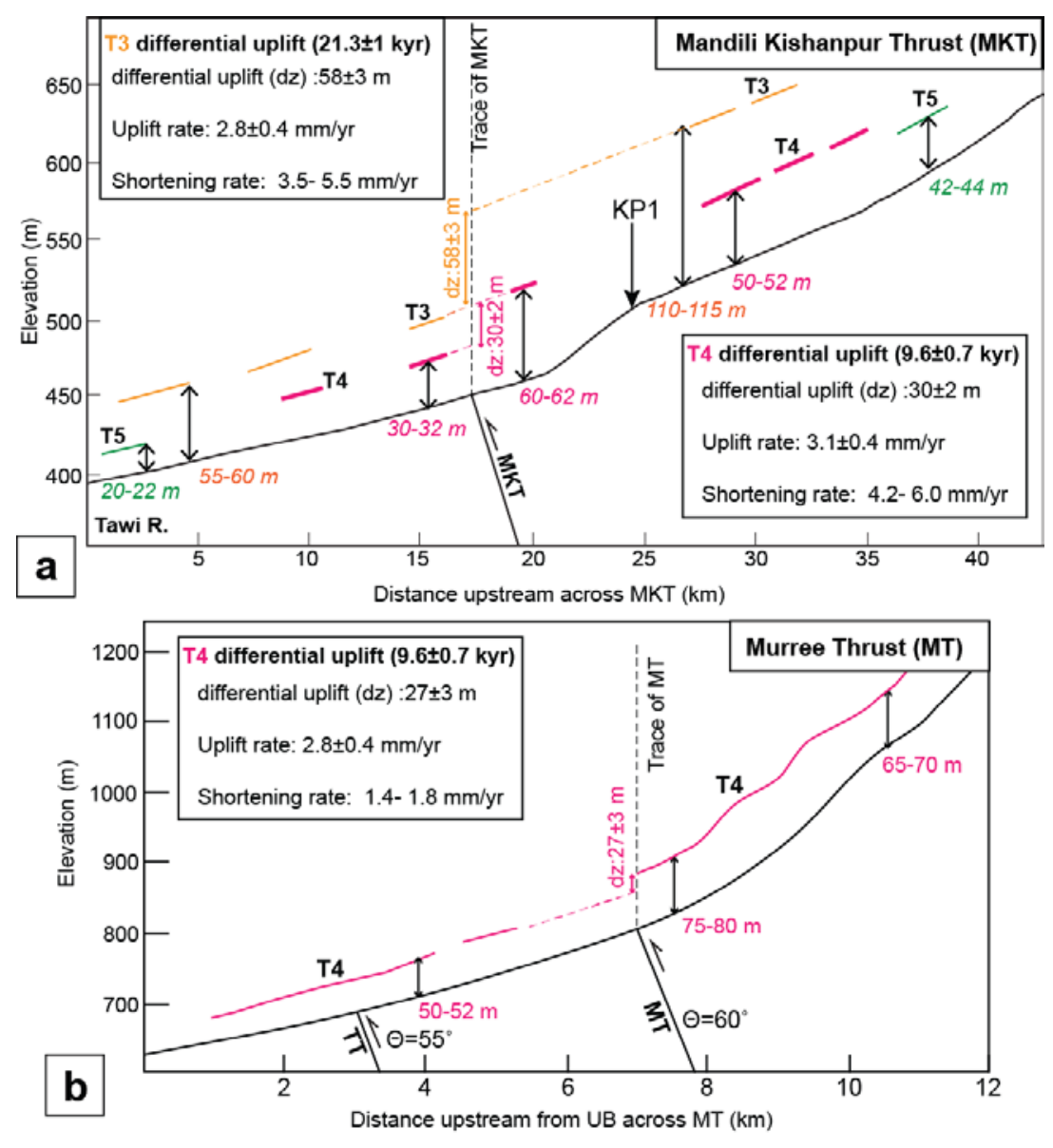

466 Figure 5: (a) Longitudinal profile of the Tawi River across the MKT showing variation in strath

467 heights. Different strath levels are projected on the trace of MKT to quantify differential uplift across 468 the MKT (following the method described in Dey et al., 2016b, cf. Fig. 7). Terrace abandonment ages 469 are used to quantify uplift rate and shortening rate (assuming $\theta$ of the fault ramp to be $30-35^{\circ}$ ) on the 470 MKT. The calculated dz value across KP1 is $15 \mathrm{~m}$. (b) Longitudinal profile of a tributary of the Tawi 471 River crossing the MT-TT fault-zone. Differential uplift of $27 \pm 3 \mathrm{~m}$ across MT is deduced from T4 472 terrace heights extracted from the DEM. Assuming the dip of the MT fault-ramp is $\sim 60^{\circ}$, this relates 473 to an estimated Holocene shortening rate of $1.6 \pm 0.2 \mathrm{~mm} / \mathrm{yr}$. 

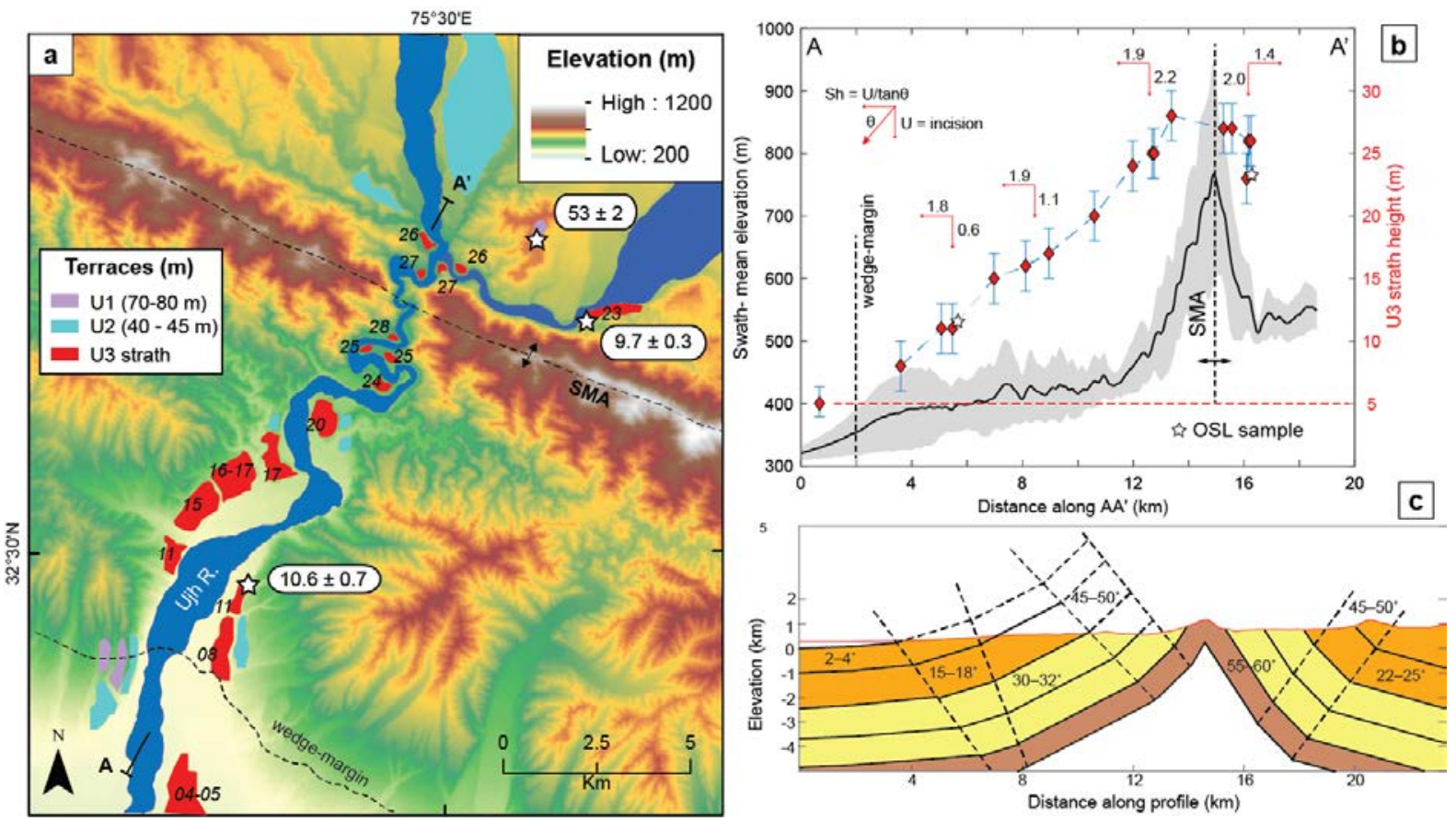

Figure 6: (a) Fluvial terrace heights (black values, in m) map along the Ujh River section. Note the change in height of the U3 strath terrace across the SMA (see Photo in Fig. 2g). The average age of

477 the strath is $10.2 \pm 0.7$ kyr. (b) Folded Siwalik topography and U3 terrace heights plotted along a swath window of 4 km along AA' (cf. Fig. 6a) show variability in U3 terrace heights along the river profile.

479 U3 terrace heights mimic the topography of the SMA, implying stronger incision rates (growth rate) 480 in the vicinity of the hinge. The component of crustal shortening at each terrace point is calculated 481 based on the differential bedrock incision (with respect to the unfolded strath height beyond the wedge-margin) and orientation of the folded strata. (c) A schematic cross-section of the SMA along Ujh River showing the structural orientation of the Siwalik strata based in our field data. 


\begin{tabular}{|c|c|c|c|c|}
\hline Structures/domain & $\begin{array}{l}\text { shortening } \\
\text { rate/growth rate } \\
(\mathrm{mm} / \mathrm{yr})\end{array}$ & Study & Area & $\begin{array}{c}\text { Time } \\
\text { averaging } \\
\text { window (kyr) }\end{array}$ \\
\hline Main Riasi Thrust (MRT) & $\sim 6-7$ & Gavillot et al., 2016 & Chenab & $\sim 100-40$ \\
\hline $\begin{array}{c}\text { Frontal Riasi Thrust } \\
\text { (FRT) }\end{array}$ & $\sim 3-6$ & Gavillot et al., 2016 & Chenab & $\sim 39-0$ \\
\hline $\begin{array}{l}\text { Medlicott Wadia Thrust } \\
\text { (MWT) }\end{array}$ & $\sim 11.2 \pm 3.8$ & Vassallo et al., 2015 & Chenab & $\sim 14-0$ \\
\hline \multirow{3}{*}{$\begin{array}{l}\text { Surain-Mastargh } \\
\text { Anticline (SMA) }\end{array}$} & $\sim 9 \pm 3.2$ & Vassallo et al., 2015 & Chenab & $\sim 24-0$ \\
\hline & $\sim 4.6$ & Gavillot, 2014 & Chenab & $\sim 53-0$ \\
\hline & $\sim 0.2-2.0$ & Jagtap et al., 2018 & Jammu & $\sim 50-7$ \\
\hline \multirow{2}{*}{$\begin{array}{l}\text { Jwalamukhi Thrust } \\
\text { (JMT) }\end{array}$} & $3.5-4.2$ & Thakur et al., 2014 & Kangra & $\sim 32-30$ \\
\hline & $5.6 \pm 0.8-7.5 \pm 1.1$ & Dey et al., 2016 & Kangra & $\sim 10-0$ \\
\hline Soan Thrust (ST) & 3.0 & Thakur et al., 2014 & Kangra & $\sim 29-0$ \\
\hline $\begin{array}{c}\text { Himalayan Frontal Thrust } \\
\text { (HFT) }\end{array}$ & $\sim 6.0 \pm 0.5$ & Thakur et al., 2014 & Kangra & $\sim 42-0$ \\
\hline
\end{tabular}

487

Table 1: Compilation of previously-published shortening rates on the active structures in the Western

SH. Note that FRT and JMT are contemporary to the MKT exposed in our study area. Please note the discrepancy in growth rate estimates for the SMA between the studies.

\begin{tabular}{|c|c|c|c|c|c|c|c|c|c|c|}
\hline Sample & Lat. $\left.\mathbf{(}^{\circ}\right)$ & $\begin{array}{c}\text { Long. } \\
\left({ }^{\circ}\right)\end{array}$ & $\begin{array}{c}\mathbf{U} \\
\mathbf{( p p m )}\end{array}$ & $\begin{array}{c}\mathbf{T h} \\
\mathbf{( p p m )}\end{array}$ & $\mathbf{K} \mathbf{( \% )}$ & $\begin{array}{c}\mathbf{H}_{\mathbf{2}} \mathbf{O} \\
\mathbf{( \% )}\end{array}$ & $\begin{array}{c}\text { Dose } \\
\text { rate } \\
\mathbf{( G y / k y r )}\end{array}$ & $\mathbf{D e} \mathbf{( G y )}$ & $\begin{array}{c}\text { OD } \\
\mathbf{( \% )}\end{array}$ & $\begin{array}{c}\text { Central } \\
\text { Age } \\
\mathbf{( k y r )}\end{array}$ \\
\hline TW-01 & 32.9137 & 75.1217 & $3.5 \pm 0.1$ & $19.6 \pm 0.2$ & $2.28 \pm 0.2$ & 5 & $4.50 \pm 0.1$ & $111 \pm 5.9$ & 12 & $24.1 \pm 1.5$ \\
TW-02 & 32.9021 & 75.1375 & $3.3 \pm 0.1$ & $15.8 \pm 0.1$ & $2.62 \pm 0.2$ & 6 & $4.55 \pm 0.2$ & $101.5 \pm 5.2$ & 13 & $22.3 \pm 1.3$ \\
TW-03 & 32.8908 & 75.1746 & $3.0 \pm 0.2$ & $12.7 \pm 0.2$ & $1.96 \pm 0.1$ & 8 & $3.49 \pm 0.1$ & $30.1 \pm 3.4$ & 10 & $8.6 \pm 1.0$ \\
TW-04 & 32.8907 & 75.1488 & $3.5 \pm 0.1$ & $9.5 \pm 0.1$ & $1.98 \pm 0.1$ & 10 & $3.31 \pm 0.1$ & $31.9 \pm 2.3$ & 9 & $9.6 \pm 0.7$ \\
TW-05 & 32.7489 & 75.1523 & $3.8 \pm 0.1$ & $18.5 \pm 0.2$ & $2.2 \pm 0.2$ & 10 & $4.04 \pm 0.2$ & $82.1 \pm 4.1$ & 9 & $20.3 \pm 0.8$ \\
TW-06 & 32.8405 & 75.0258 & $3.4 \pm 0.1$ & $9.5 \pm 0.4$ & $2.0 \pm 0.1$ & 9 & $3.72 \pm 0.1$ & $36.9 \pm 3.0$ & 14 & $9.7 \pm 0.7$ \\
UJ-01 & 32.4812 & 75.4348 & $3.5 \pm 0.1$ & $14.2 \pm 0.3$ & $2.1 \pm 0.1$ & 8 & $3.50 \pm 0.1$ & $37.2 \pm 3.1$ & 12 & $10.6 \pm 0.8$ \\
UJ-02 & 32.5584 & 75.5467 & $3.4 \pm 0.1$ & $9.5 \pm 0.4$ & $2.0 \pm 0.1$ & 8 & $3.72 \pm 0.1$ & $36.0 \pm 3.0$ & 14 & $9.8 \pm 0.8$ \\
UJ-03 & 32.5807 & 75.5314 & $3.9 \pm 0.2$ & $14.1 \pm 0.1$ & $1.7 \pm 0.1$ & 6 & $3.10 \pm 0.1$ & $165 \pm 6.1$ & 7 & $53 \pm 2$
\end{tabular}


492 Table 2: Details of OSL samples, elemental concentrations, dose rate, equivalent dose and central age 493 (after Bailey and Arnold, 2006).

\begin{tabular}{|c|c|c|c|}
\hline & $\begin{array}{c}\text { Bedrock } \\
\text { incision } \\
\text { (m) }\end{array}$ & $\begin{array}{c}\text { Age } \\
\text { (kyr) }\end{array}$ & $\begin{array}{l}\text { Incision/ } \\
\text { Uplift rate } \\
\text { (mm/yr) }\end{array}$ \\
\hline
\end{tabular}

\section{MKT hanging wall}

$\begin{array}{cccr}\text { TW-02 } & \sim 115 & 22.3 \pm 1.3 & 5.2 \pm 0.3 \\ \text { TW-04 } & \sim 52 & 9.6 \pm 0.7 & 5.4 \pm 0.4 \\ \text { TW-03 } & \sim 44 & 8.6 \pm 1.0 & 5.1 \pm 0.6 \\ \text { MKT footwall / SMA } & \text { northern limb (Tawi) } \\ \text { TW-05 } & \sim 55 & 20.3 \pm 0.8 & 2.7 \pm 0.1 \\ \text { TW-06 } & \sim 27 & 9.7 \pm 0.7 & 2.8 \pm 0.2\end{array}$

MKT footwall/ SMA northern limb (Ujh)

$\begin{array}{cccc}\text { UJ-02 } & 23 & 9.8 \pm 0.8 & 2.3 \pm 0.2 \\ \text { UJ-03 } & 70 & 53 \pm 2 & 1.3 \pm 0.1\end{array}$

SMA southern limb (Ujh)

494
$\mathrm{UJ}-01$
11
$10.6 \pm 0.8$
$1.0 \pm 0.1$

495 Table 3: Bedrock incision rates across the MKT measured from variable strath heights exposed along 496 the Tawi River.

497

498 